\title{
Perancangan Aplikasi Komputer Berbasis Android untuk Panduan Pengawasan Pembangunan Kapal Baru oleh Owner Surveyor
}

\author{
Joshua Adrian Lasuardi, Triwilaswandio Wuruk Pribadi \\ Jurusan Teknik Perkapalan, Fakultas Teknologi Kelautan, Institut Teknologi Sepuluh Nopember (ITS) \\ Jl. Arief Rahman Hakim, Surabaya 60111 Indonesia \\ e-mail: triwilas.its@gmail.com
}

\begin{abstract}
Abstrak - Kegiatan pengawasan pembangunan kapal baru yang ada saat ini masih dilakukan secara manual dimana seorang owner surveyor melakukan pengawasan mengacu pada form pengawasan. Kegiatan pengawasan yang ada saat ini kurang efektif untuk dilakukan pada proses pembangunan kapal baru, hal ini dikarenakan tidak semua owner surveyor memiliki pengetahuan dan pengalaman yang sama. Tujuan dari tugas akhir ini adalah melakukan observasi sistem pengawasan pembangunan kapal baru yang ada saat ini, merancang aplikasi komputer berbasis android untuk panduan pengawasan pembangunan kapal baru, dan melakukan uji validitas aplikasi tersebut dalam meningkatkan efektivitas pengawasan pembangunan kapal baru. Perancangan aplikasi dilakukan dengan pembuatan mock up aplikasi, desain interface, perancangan database, dan pengkodingan aplikasi tersebut. Aplikasi ini memiliki fitur daftar proses pengawasan, review hasil pengawasan, progress pembangunan kapal, dan menu untuk menambahkan owner surveyor. Uji coba aplikasi ini dilakukan kepada beberapa responden yang memiliki pengalaman pengawasan pembangunan kapal baru dan pihak-pihak yang memiliki latar belakang pendidikan di bidang perkapalan. Dari hasil pengujian menggunakan kuisoner tersebut diperoleh kesimpulan bahwa aplikasi ini perlu diaplikasikan dalam mendukung proses pengawasan pembangunan kapal baru.
\end{abstract}

Kata Kunci- Aplikasi Komputer, Pengawasan Pembangunan Kapal Baru, Owner Surveyor, Aplikasi Android Pengawasan Pembangunan Kapal Baru.

\section{PENDAHULUAN}

$\mathrm{K}$ APAL mempunyai peranan penting sebagai alat transportasi laut, baik perdagangan maupun transportasi penumpang. Seiring dengan hal tersebut, perkembangan industri manufaktur seperti galangan kapal juga mengalami peningkatan. Hal ini tentunya memperoleh perhatian khusus pihak pemilik kapal (owner) yang ingin memesan kapal. Perhatian khusus tersebut berupa pengawasan dalam proses pembangunan kapal baru. Pada kondisi nyata di lapangan semakin banyaknya proses pembangunan kapal baru menyebabkan semakin meningkatnya kebutuhan owner surveyor. Semakin bertambahnya kebutuhan pengawasan pembangunan kapal baru menyebabkan banyaknya owner surveyor baru yang secara pengalaman dan pengetahuan kurang memadai.
Kesusahan terjadi apabila owner surveyor haru melakukan pengawasan dengan menggunakan laptop. Selain itu laporan hasil pengawasan ini dikemas dalam bentuk laporan yang diinput secara manual dan memakan waktu yang relatif lebih lama.

\section{STUDI LITERATUR}

\section{A. Proses Pembangunan Kapal Secara Umum}

Proses pembangunan kapal (shipbuilding process) adalah suatu proses yang sangat kompleks yang dimulai dari perumusan permintaan pemesan kapal (spesifikasi teknis kapal) hingga penyerahan kapal oleh pihak galangan kepada pemesan kapal. Oleh karena itu galangan harus mampu menterjemahkan apa yang diinginkan pemesan kapal [1]. Tahapan-tahapan dalam proses pembangunan kapal dapat diuraikan secara umum sebagai berikut [2]:

1) Development of owner's requirement

2) Preliminary/concept design

3) Contract design

4) Bidding/contract

5) Detail design and planning

6) Construction

\section{B. Kegiatan Pengawasan Pembangunan Kapal Baru}

Dalam proses pembangunan kapal baru diperlukan kegiatan pengawasan dan pemeriksaan untuk menilai konstruksi kapal dan material yang dipakai seluruhnya pada sebelum, ketika, dan sesudah proses fabrikasi. Kapal diperiksa dan diuji untuk membuktikkan proses pembangunan kapal apakah sudah sesuai dengan yang ada pada desain. Ketika kapal sedang dalam tahap pembangunan, material, mesin, peralatan, perpipaan, perlengkapan kelistrikan, dan perlengkapan lainnya ketika sampai di galangan juga harus diperiksa.melakukan updating terhadap dokumen-dokumen kapal.

\section{Progress Pembangunan Kapal}

Progress pembangunan kapal adalah penilaian terhadap kemajuan fisik pembangunan kapal di galangan [3]. Penilaian kemajuan fisik pembangunan kapal di galangan diperoleh dari kegiatan pengawasan. Fungsi dari perhitungan progress 
pembangunan kapal adalah untuk memperoleh termin pembayaran owner ke galangan kapal. Besaran nilai termin diperoleh dari hasil kesepakatan owmer dan galangan kapal. Apabila progress pembangunan kapal sudah tercapai sesuai dengan kesepakatan, maka termin pembayaran tersebut bisa turun.

\section{Tujuan Pengawasan dan Pemeriksaan}

Tujuan pekerjaan pengawasan dan pemeriksaan dari proyek pembangunan kapal baru antara lain :

1) Mengidentifikasi kesuluruhan material yang digunakan dalam proses pembangunan kapal mulai dari pemesanan hingga material tersebut tiba di galangan.

2) Mengetahui informasi standar kualitas pengerjaan dari lambung dan material outfitting pada sebelum, saat, dan setelah fabrikasi.

3) Mengevaluasi kualitas pengerjaan dari lambung dan material outfitting pada sebelum, saat, dan setelah fabrikasi.

4) Mengevaluasi perbedaan-perbedaan daya, kapasitas, dan kualitas mesin/peralatan/perlengkapan antara saat di pabriknya, saat di galangan dan saat sea trial.

\section{E. Owner Surveyor}

Pada sebuah proses pengawasan dan pemeriksaan sebuah kapal dibutuhkan seseorang yang bertanggung jawab kepada owner untuk melaporkan segala bentuk kegiatan serta hasil pemeriksaan/pengawasan yang disebut Owner Surveyor kapal. Owner Surveyor kapal itu sendiri merupakan seseorang yang ahli atau merupakan pakar dalam melakukan berbagai macam bentuk pengawasan, pemeriksaan, maupun survei kondisi kapal.

\section{F. Aplikasi Komputer Berbasis Android}

Perangkat lunak (software) adalah instruksi langsung komputer untuk melakukan pekerjaan dan dapat ditemukan di setiap aspek kehidupan modern dari aplikasi yang kritis untuk hidup (life-critical), seperti perangkat pemantauan medis dan pembangkit tenaga listrik sampai perangkat hiburan, seperti video game [4].

Android adalah sistem operasi yang berbasis Linux untuk telepon seluler seperti telepon pintar dan komputer tablet [5]. Android Standart Development Kit (SDK) menyediakan perlengkapan dan Application Programming Interface (API) yang diperlukan untuk mengembangkan aplikasi pada platform Android menggunakan bahasa pemrograman Java. Android dikembangkan oleh Google bersama Open Handset Allience (OHA) yaitu aliansi perangkat selular terbuka yang terdiri dari 47 perusahaan Hardware, Software dan perusahaan telekomunikasi ditujukan untuk mengembangkan standar terbuka bagi perangkat selular.

\section{METODOLOGI PENELITIAN}

\section{A. Studi Lapangan}

Studi lapangan dilakukan untuk memperoleh data dan informasi yang terkait dengan pengerjaan Tugas Akhir. Studi lapangan dilakukan di perusahaan pemilik kapal (PT. Pertamina Perkapalan) dan galangan tempat kapal perusahaan tersebut dibangun (PT. PAL Indonesia). Berikut langkah-langkah yang dilakukan untuk memperoleh data dari studi lapangan:

1) Mempelajari skema pemeriksaan biro klasifikasi kapal

2) Mengidentifikasi item pemeriksaan proses pembangunan kapal

3) Mengidentifikasi alur proses pengawasan owner surveyor

4) Mengumpulkan standar pemeriksaan galangan, owner, dan biro klasifikasi

5) Mempelajari contoh progress pembangunan kapal dan cara perhitungan progress tersebut

6) Mengumpulkan data contoh dokumen laporan pengawasan dan form pengawasan

\section{B. Studi Pustaka}

Studi pustaka yang dilakukan meliputi tinjauan dasar teori yang relevan dengan penelitian dan mendukung dalam percancangan aplikasi, berikut studi pustaka yang berkaitan dengan penelitian ini:

1) Mempelajari alur proses pembangunan kapal baru

2) Mempelajari buku manual pembangunan kapal untuk para pengawas

3) Mempelajari buku pemrograman aplikasi komputer berbasis android

4) Melakukan review penelitian terdahulu

\section{Pengolahan Data}

Tahap pengolahan data merupakan tahap dimana data-data yang telah diperoleh dari sumber referensi diolah untuk menyusun kerangka aplikasi yang akan dibuat. Berikut beberapa tahapan dalam mengolah data:

1) Pengelompokkan bagian kapal dan proses-proses pengerjaan pembangunan kapal baru.

2) Pembuatan daftar pengawasan pembangunan kapal baru.

3) Pembuatan daftar item pemeriksaan pembangunan kapal baru.

\section{Perancangan Program Aplikasi Android}

Perancangan aplikasi dilakukan dengan cara sebagai berikut:

1) Pembuatan mock up aplikasi dalam Microsoft Word

2) Desain interface atau tampilan pada aplikasi android yang akan dibuat

3) Perancangan database proses pengawasan pembangunan kapal baru

4) Pengcodingan

\section{SISTEM PENGAWASAN PEMBANGUNAN KAPAL BARU}

\section{A. Pengawasan Pembangunan Kapal Baru}

Dalam proses pembangunan kapal setiap pemilik kapal selalu mengharuskan adanya proses pengawasan dan pemeriksaan. Proses tersebut harus dilakukan karena dapat mengurangi cacat pengerjaan dan masalah-masalah teknis lainnya yang dapat menghambat proses pembangunan kapal 
baru. Selain itu kegiatan pengawasan dan pemeriksaan sangat diperlukan demi menjaga standar kualitas pengerjaan kapal tersebut sesuai dengan peraturan Biro Klasifikasi, spesifikasi teknis, kontrak, gambar/drawing dari kapal tersebut, peraturan statutori, dan standar dari galangan itu sendiri. Untuk mempermudah pembagian aktifitas pengawasan dan pemeriksaan maka pihak galangan, pihak pemilik kapal, bersama pihak Biro Klasifikasi memiliki acuan yaitu Inspection and Test Plan (ITP).

\section{B. Form Pengawasan}

Form pengawasan merupakan form yang dikeluarkan oleh pihak pemilik kapal sebagai acuan seorang owner surveyor dalam melakukan pekerjaannya. Berikut penulis menampilkan contoh form pengawasan yang diperoleh dari PT. Pertamina Perkapalan:

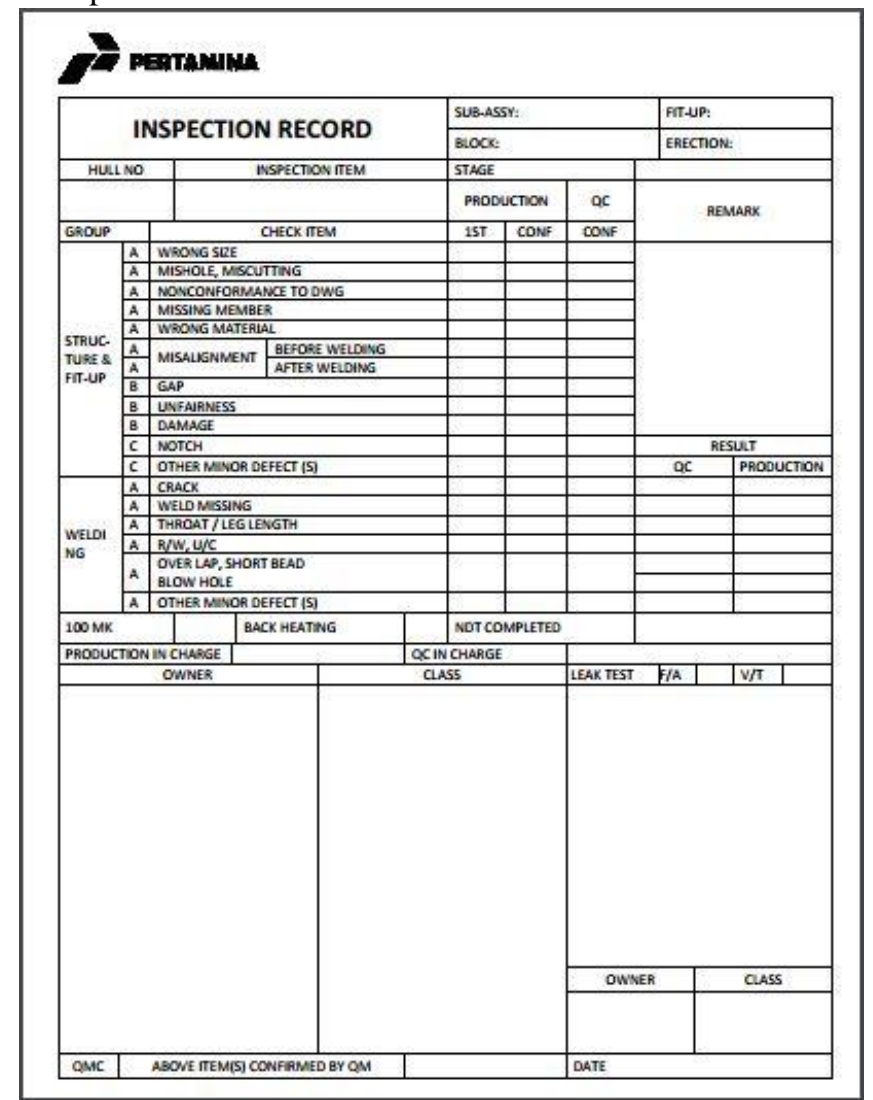

Gambar. 1. Contoh form pengawasan kapal PT. Pertamina Perkapalan

Form pengawasan pada Gambar 1 merupakan salah satu contoh form pengawasan yang biasa digunakan oleh Owner Surveyor dalam melakukan kegiatan pengawasan. Pada kenyataannya di lapangan form tersebut harus didiskusikan juga dengan pihak galangan untuk memperoleh kesepakatan form pengawasan yang digunakan. Form pengawasan yang telah diisi dan hasil pemeriksaan/pengawasan disajikan dalam bentuk laporan pengawasan kepada pihak pemilik kapal.

\section{Laporan pengawasan}

Bentuk laporan yang disajikan dalam sistem tersebut adalah print out dari laporan yang diketik secara langsung berdasarkan data yang diperoleh dari survey list ketika Owner Surveyor melakukan survei kondisi. Bentuk laporan survei dapat dilihat pada Gambar 2 berikut:

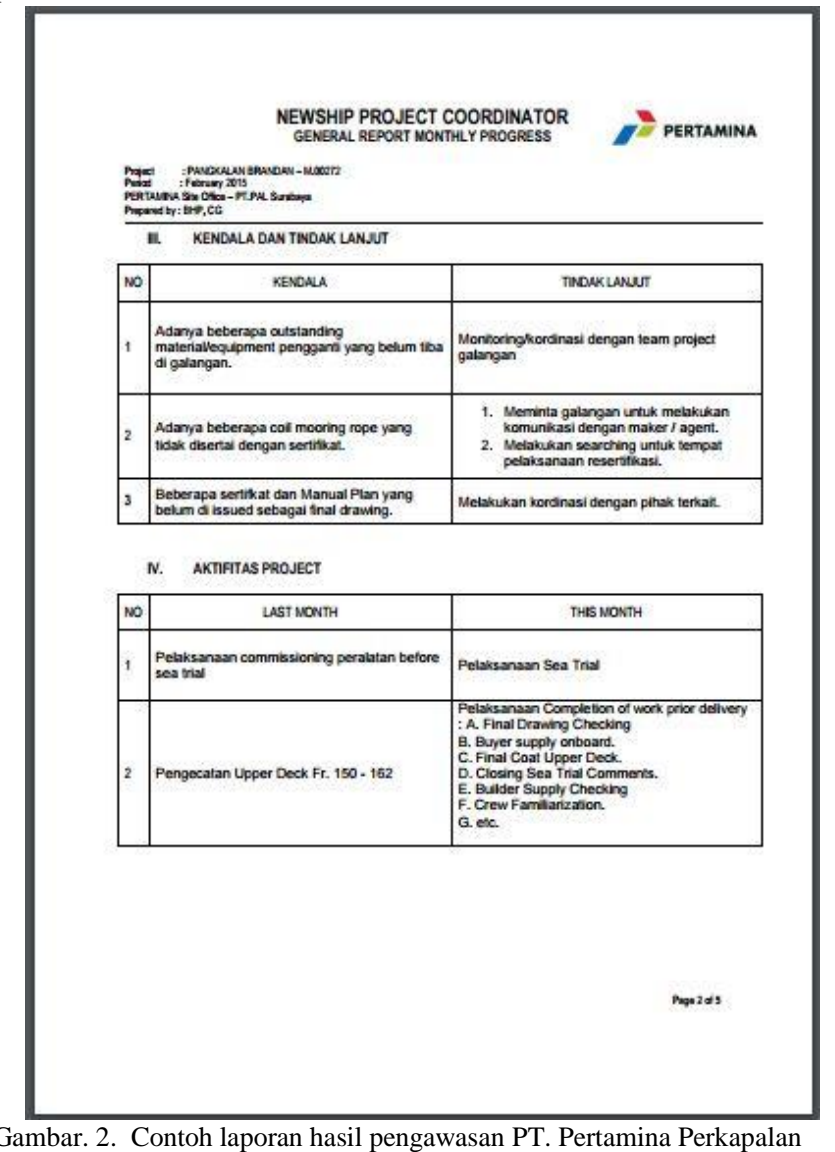

Gambar 2, merupakan contoh laporan pengawasan yang ada saat ini. Pada laporan pengawasan ini terdapat identitas kapal dan hasil-hasil pengawasan selama di lapangan. Selain itu untuk menunjukkan keadaan kapal sesungguhnya seorang Owner Surveyor juga memasukkan foto ke dalam laporan pengawasan.

\section{Kelemahan Proses Pengawasan Pembangunan Kapal Baru Saat ini}

Pada bagian ini dijelaskan apa saja yang menjadi kelemahan sistem yang ada saat ini. Dalam melakukan pengawasan, seorang owner surveyor dari sebuah perusahaan pelayaran atau perusahaan pemilik kapal yang cukup besar (memiliki kapal lebih dari satu) biasanya mengawasi lebih dari satu kapal. Selain itu semakin berkembangnya industri perkapalan nasional membuat kebutuhan owner surveyor untuk mengawasi proses pembangunan kapal baru meningkat. Penambahan jumlah pengawas dengan menggunakan owner surveyor muda atau biasa disebut junior surveyor merupakan solusi bagi kegiatan pengawasan, namun minimnya pengalaman dan pengetahuan dari junior surveyor tersebut membuat perusahaan pemilik kapal atau perusahaan pelayaran harus melakukan training/pelatihan terlebih dahulu. Hal tersebut memakan waktu yang cukup lama dan perusahaan pemilik kapal atau perusahaan pelayaran tersebut menjadi terkendala, sedangkan armada dari perusahaan tersebut terus bertambah sehingga dibutuhkannya seorang owner surveyor yang berpengalaman. 
Proses pengawasan pembangunan kapal baru yang ada saat ini dilakukan secara manual dengan lembaran pengawasan oleh owner surveyor ketika melakukan pengawasan pembangunan kapal baru. Dari hasil pengawasan yang diperoleh selama di lapangan, owner surveyor memasukkan hasil tersebut secara manual ke laptop atau $p c$ dan disajikan dalam bentuk laporan yang disertai foto/gambar dokumentasi selama melakukan pengawasan. Proses yang cukup lama menyebabkan pengawasan pembangunan kapal baru yang ada saat ini menjadi kurang efektif dan kurang efisien. Selain itu penyimpanan form maupun laporan pengawasan yang berupa kertas menyebabkan sangat mudah terjadinya kehilangan maupun kerusakan. Hal ini juga sangat menghambat dikarenakan setiap dokumen proses pengawasan dapat menjadi acuan dalam meberikan penilaian terhadap progress dari kapal terebut.

\section{PERANCANGAN PROGRAM APLIKASI}

\section{A. Penjelasan Umum Program Aplikasi}

Software application ini berbasis android sehingga bersifat portable. Aplikasi android juga merupakan jenis perangkat lunak yang friendly to user, namun untuk membuat aplikasi ini bisa berjalan lebih baik maka diperlukan user yang berpengalaman di dalam dunia perkapalan.

Aplikasi ini memiliki dua fungsi $\log$ in yaitu: $\log$ in sebagai administrator dan yang kedua log in sebagai owner surveyor. Dalam hal ini fungsi $\log$ in administrator adalah untuk melakukan input item pengawasan, editing parameter pengawasan, dan mengakses laporan hasil pengawasan. Fungsi yang selanjutnya adalah log in owner surveyor yang dit ujukan untuk owner surveyor yang hendak melakukan pengawasan pembangunan kapal baru. Dalam proses pengawasan pembangunan kapal baru seorang owner surveyor dapat memanfaatkan aplikasi ini untuk melakukan pengawasan dengan mengisi form yang tersedia. Pengisian form pada aplikasi tersebut dilakukan berdasarkan hasil fakta yang ada di lapangan. Hasil pengawasan akan disimpan ke server sehingga laporan dapat diakses oleh pihak administrator.

\section{B. Penyusunan Database}

Penyusunan database tugas akhir ini disusun dari form pengawasan yang telah diolah berdasarkan data yang telah diperoleh. Meskipun setiap perusahaan pelayaran memiliki form pengawasan yang berbeda, namun berdasarkan studi lapangan yang dilakukan maka diperoleh form pengawasan yang lebih sistematis dan mempermudah owner surveyor dalam melakukan proses pengawasan khusunya bagi junior surveyor. Form pengawasan yang dibuat dibagi menjadi beberapa bagian dimulai dari document, procurement, fabrikasi, assembly, erection, outfitting, launching, commisioning, sea trial, delivery, dan meeting. Setiap bagian memiliki kalimat panduan pengawasan, file panduan pengawasan, dan gambar ITP yang dapat membantu seorang junior surveyor dalam melakukan pengawasan. Form pengawasan yang ditampilkan berupa checklist dan penginputan teks dan angka secara manual. Data hasil pengawasan user dapat dilihat di aplikasi administrator.

\section{Simulasi Aplikasi}

Adapun simulasi tampilan aplikasi komputer berbasis android untuk panduan pengawasan pembangunan kapal baru adalah sebagai berikut:

\section{1) Administrator}

Administrator merupakan pengguna dari aplikasi ini yang memiliki kewenangan untuk memanajemen pengguna aplikasi ini, memasukkan data kapal, memasukkan bantuan untuk proses pengawasan, memasukkan file/gambar yang digunakan untuk melakukan proses pengawasan, melihat hasil laporan pengawasan, dan memasukkan progress pembangunan kapal berdasarkan hasil laporan pengawasan.

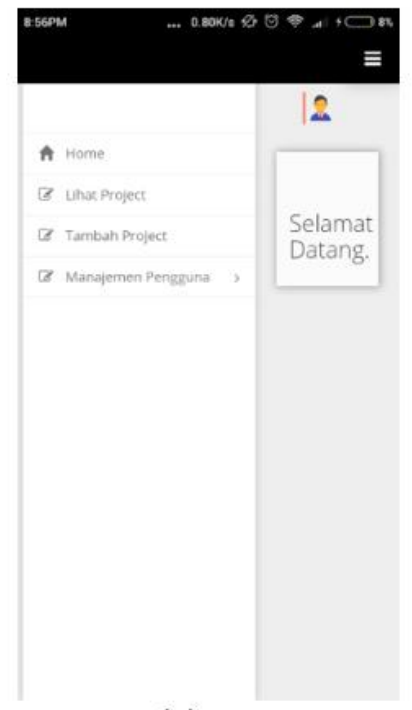

(a)

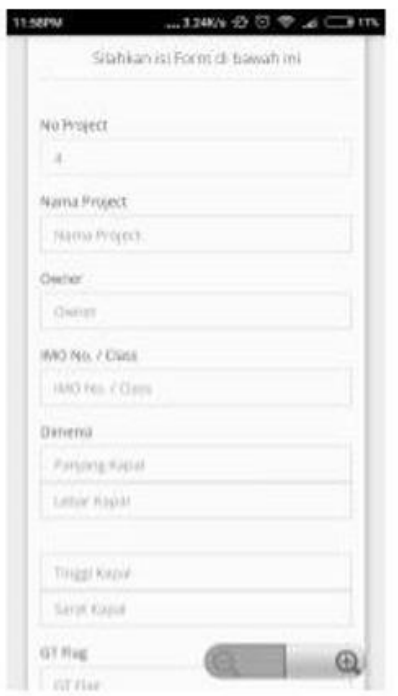

(b)
Gambar. 3. Fasilitas menu pilihan pada aplikasi dan (b) Proses pengisian data kapal

Gambar 3(a) merupakan tampilan dari menu utama setelah Administrator melakukan log in. Pada halaman menu ditampilkan beberapa pilihan untuk Administrator dalam menjalankan aplikasi android. Pada kondisi ini dilakukan pemilihan menu tambah project sehingga ditampilkan form pengisian data kapal seperti Gambar 3(b) diatas. Data kapal yang diisi oleh Administrator tersimpan pada server dan dapat di akses untuk ditampilkan pada aplikasi yang digunakan User. Hal ini bertujuan untuk mempermudah User dalam memilih dan menampilkan data kapal yang hendak di survei tanpa harus dilakukannya pendataan dari awal oleh User.

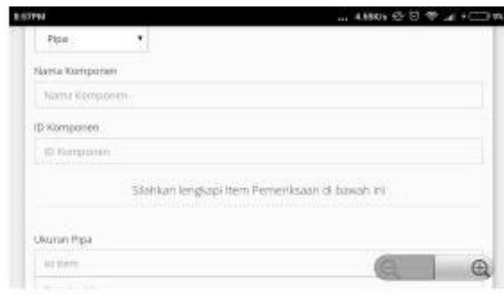

(a)

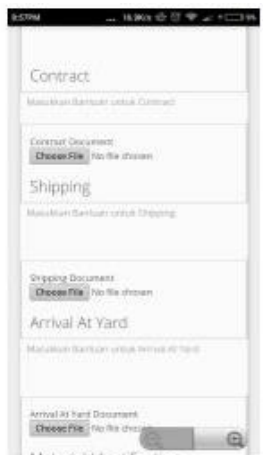

(b)
Gambar. 4. (a) Form data procurement dan (b) Form input bantuan dan file 
Gambar 4(a) merupakan form pengisian data komponen kapal. Data komponen tersebut yang telah diisi tersimpan dan dapat diakses oleh User ketika melakukan pengawasan di lapangan. Gambar 4(b) merupakan form pengisian bantuan dan input file sebagai panduan user di lapangan.

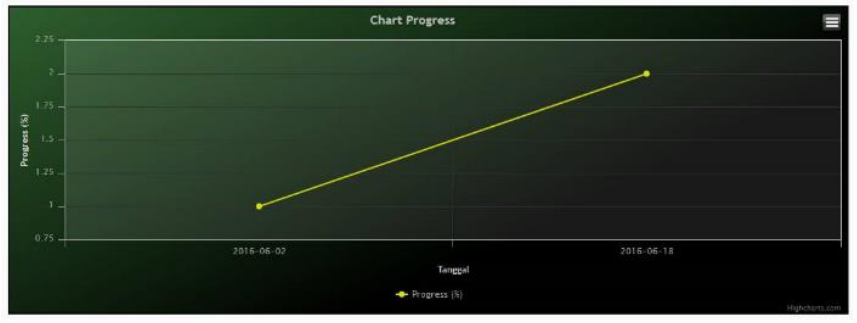

Gambar. 5. Contoh grafik progress pembangunan kapal

Gambar 5 merupakan contoh grafik progress pembangunan kapal yang nilainya dimasukkan secara manual oleh administrator. Progress tersebut menampilkan prosentase per tanggal input hingga sampai sumbu y maksimum yang merupakan prosentase progress sebuah proses pengawasan.

\section{2) User}

User adalah pengguna aplikasi android ini selama di lapangan. User dalam aplikasi ini adalah owner surveyor. Kegiatan-kegiatan yang dilakukan oleh owner surveyor adalah memilih kapal yang diawasi, mengisi form-form pengawasan yang tersedia, dan mendokumentasikan proses pengawasan yang dilakukan.

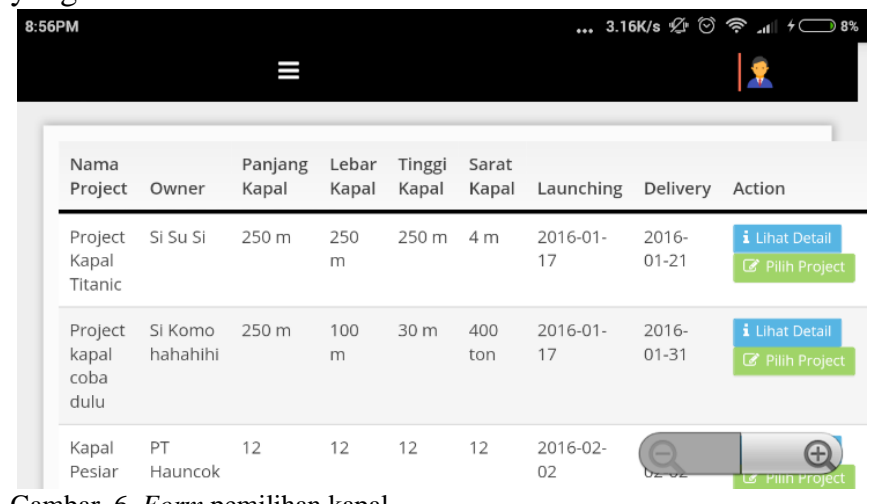

Gambar. 6. Form pemilihan kapal

Gambar 6 merupakan proses dari pemilihan kapal yang dilakukan oleh User setelah melakukan fungsi $\log$ in. Setelah melakukan pemilihan kapal maka dapat dilakukan pemilihan proses pembangunan kapal yang hendak diawasi.

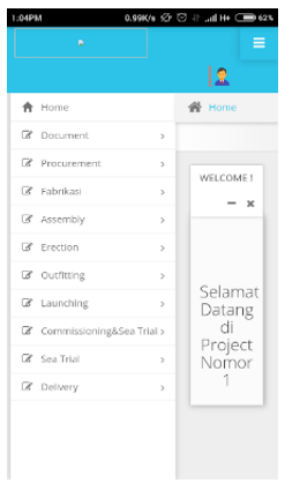

(a)

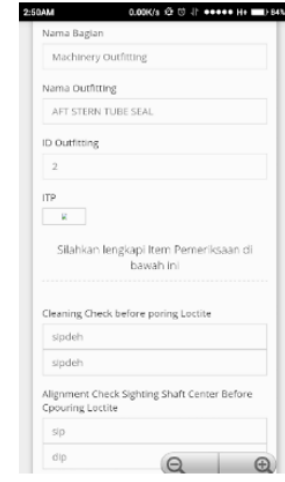

(b)

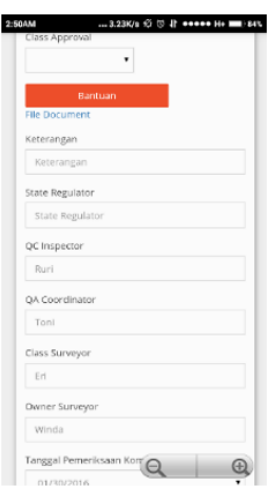

Gambar. 7. (a) Pemilihan proses pengawasan dan (b) Form pengawasan secara berurutan
Gambar 7(a) proses pengawasan yang dapat dipilih oleh user. Setelah dilakukannya pemilihan terhadap outfitting, memilih machinery outfitting, dan memilih aft stern tube seal maka ditampilkan form pengawasan seperti Gambar 7(b).

\section{ANALISA SISTEM DAN UJI COBA APLIKASI}

\section{A. Analisa Sistem}

Berikut hasil perbandingan sistem yang ditampilkan pada tabel 1 di bawah ini

Tabel 1.

Analisa perbandingan kelebihan dan kekurangan sistem

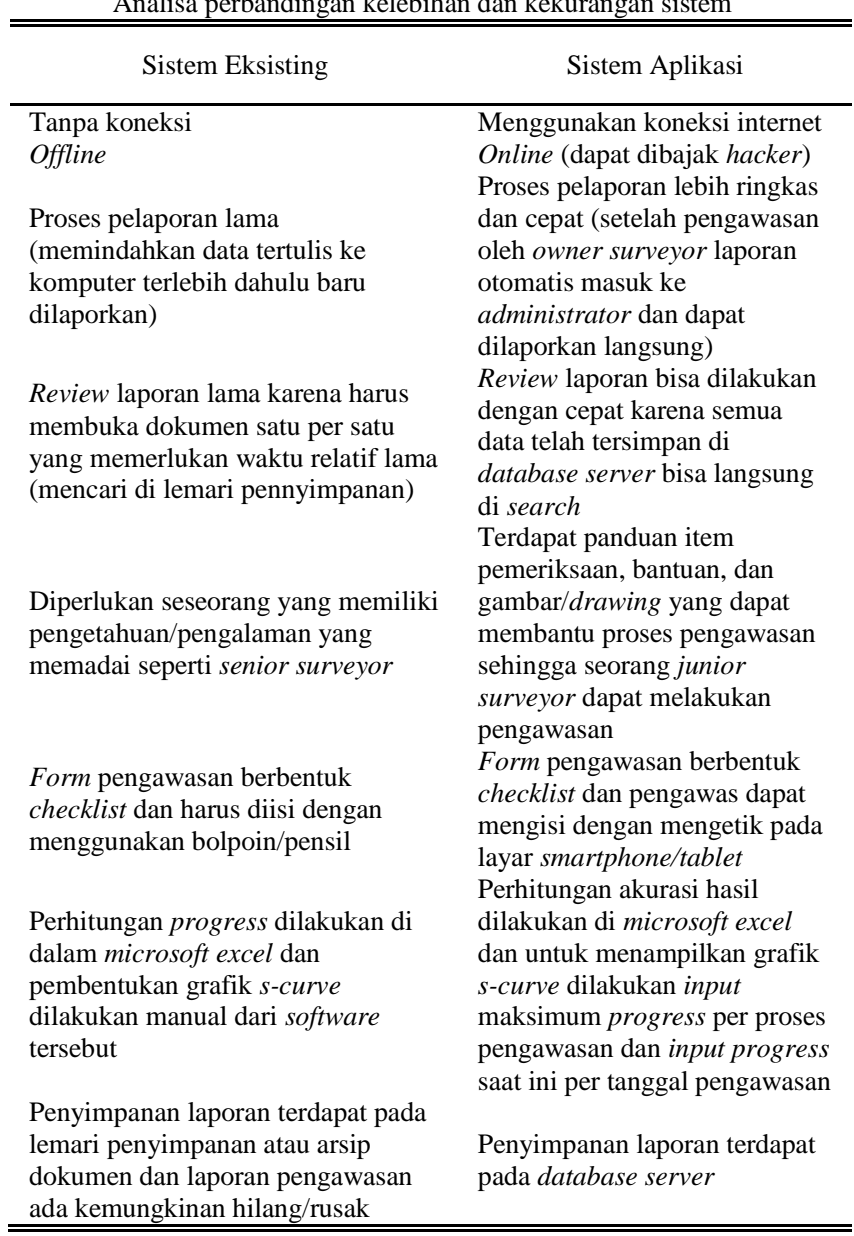

Dari Tabel 1 dapat dilihat perbandingan antara sistem eksisting dengan sistem aplikasi yang dirancang. Dalam tabel tersebut terdapat kelebihan maupun kekurangan dari sistem eksisting maupun sistem aplikasi.

\section{B. Uji Coba Aplikasi}

Untuk menganalisa kelayakan, program diaplikasikan ke pada pihak-pihak yang memiliki pengalaman pengawasan pembangunan kapal baru dan pihak-pihak yang memiliki latarbelakang pendidikan di bidang perkapalan. Pengujian ini dalam bentuk kuisioner untuk mengetahui respon pihak-pihak yang nantinya terkait apabila program ini diaplikasikan seperti Gambar 8 dibawah. 


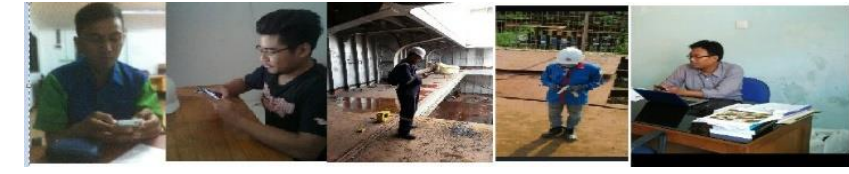

Gambar. 8. Pengujian aplikasi oleh responden

\section{KESIMPULAN}

\section{A. Kesimpulan}

1) Sistem pengawasan pembangunan kapal baru yang ada saat ini:

a. Masih dilakukan secara manual oleh owner surveyor menggunakan form pengawasan. Seorang owner surveyor melakukan pengisian form pengawasan berdasarkan apa yang dilihat atau ditemukan di lapangan dan melakukan dokumentasi berupa foto.

b. Dalam proses pelaporan hasil pengawasan seorang owner surveyor merekap keseluruhan proses pengawasan yang dilakukan dan memasukkannya ke dalam komputer. Laporan hasil pengawasan tersebut dilengkapi keterangan maupun rekomendasi yang diberikan oleh pihak-pihak terkait selama proses pengawasan di lapangan.

c. Dengan menggunakan sistem pengawasan pembangunan kapal baru yang ada saat ini proses memasukkan data form pengawasan dan pembuatan laporan pengawasan membutuhkan waktu yang lama sehingga kurang efektif.

2) Aplikasi komputer berbasis android untuk panduan pengawasan pembangunan kapal baru oleh owner surveyor yang dirancang:

a. Telah berdasarkan hasil survei yang dilakukan di lapangan dengan mengadopsi form pengawasan serta item pemeriksaan yang dilakukan pada keadaan aktual.

b. Aplikasi ini terdiri dari dua entity yaitu administrator dan user. Dalam aplikasi ini administrator memiliki kewenangan untuk memasukkan data-data kapal yang diawasi, panduan pengawasan untuk owner surveyor, item-item pemeriksaan dari masing-masing proses pengawasan, dan progress pembangunan kapal. Selain itu administrator dapat melihat hasil pengawasan yang dilakukan oleh user (owner surveyor). Selanjutnya adalah kewenangan user (owner surveyor) dalam aplikasi ini adalah melakukan pengawasan dengan menggunakan form yang terdapat pada aplikasi dan menyimpan hasil pelaporan pengawasan. Selain itu user dapat memasukkan foto-foto dokumentasi selama proses pengawasan.

c. Kelemahan pada aplikasi ini adalah progress dimasukkan secara manual dengan melakukan input prosentase progress. Untuk akurasi perhitungan dilakukan dengan menggunakan Microsoft Excel.

3) Sistem pengawasan pembangunan kapal baru dapat diimplementasikan dalam bentuk aplikasi komputer berbasis android: a. Aplikasi ini memiliki kelebihan dalam melakukan penyajian laporan secara otomatis ketika user (owner surveyor) telah melakukan pengisian form pengawasan dari hasil pengawasan di lapangan. Laporan pengawasan dapat diakses oleh administrator dalam waktu yang bersamaan setelah laporan tersebut diinput oleh user. Dengan sistem baru menggunakan aplikasi ini, seorang owner surveyor dapat melakukan pengemasan laporan hasil pengawasan dan penyampaian hanya dalam hitungan menit.

b. Aplikasi ini telah diujicobakan kepada beberapa responden yang memiliki pengalaman pengawasan pembangunan kapal baru dan pihak-pihak yang memiliki latar belakang pendidikan di bidang perkapalan. Pengujian ini dilakukan dalam bentuk penjelasan mengenai aplikasi terlebih dahulu beserta fitur-fitur yang terdapat dalam aplikasi tersebut, setelah itu dilakukan running aplikasi oleh beberapa responden dilanjutkan dengan pengisian kuisioner yang bertujuan untuk mengetahui penilaian para responden terhadap aplikasi ini. Dari hasil kuisioner dapat disimpulkan bahwa aplikasi ini perlu diaplikasikan dalam mendukung kegiatan pengawasan pembangunan kapal baru.

\section{UCAPAN TERIMA KASIH}

Penulis mengucapkan terima kasih kepada Ayah dan Ibu tercinta yang telah membesarkan penulis atas do'a, kasih sayang, dukungan, dan bimbingannya yang tidak pernah berhenti

Penulis mengucapkan terima kasih kepada Bapak Ir. Triwilaswandio Wuruk Pribadi, M.Sc. selaku dosen pembimbing yang telah membimbing penelitian ini sampai terbitnya jurnal ini.

\section{DAFTAR PUSTAKA}

[1] G. F. Satriya, "Perancangan Sistem Informasi Manajemen Proyek Pembangunan Kapal Baru," Jurusan Teknik Perkapalan FTK - ITS, Surabaya, 2002.

[2] R. L. Storch, Ship Production (Second Edition), Centreville Maryland: Cornell Maritime Press, 1995.

[3] N. K. Rad, "Plan Academy: Primavera P6 Online Training \& Video," Physical Percent Complete in Primavera, [Online]. Available: https://www.planacademy.com/primavera-p6-physical-percent-completeguide/. [Accessed 23 June 2016].

[4] J. Sinamarta, Rekayasa Perangkat Lunak, Yogyakarta: Andi Offset, 2010.

[5] L. Wijaya, "Penerapan Web Service pada Aplikasi Sistem Akademik pada Platform Sistem Operasi Mobile Android 6," 2012. 